\title{
Tsunami in Guadeloupe (Caribbean Sea)
}

\author{
Irina Nikolkina* $^{* 1,2}$, Narcisse Zahibo ${ }^{1}$ and Efim Pelinovsky ${ }^{1,3}$ \\ ${ }^{1}$ Physics Department, University of the French West Indies and Guiana, Pointe-à-Pitre, Guadeloupe, France \\ ${ }^{2}$ Department of Applied Mathematics, Nizhny Novgorod State Technical University, Nizhny Novgorod, Russia \\ ${ }^{3}$ Department of Nonlinear Geophysical Processes, Institute of Applied Physics, Nizhny Novgorod, Russia
}

\begin{abstract}
Detailed analysis of historical data of tsunamis for 1498-2008 period in Guadeloupe (French West Indies, Caribbean sea), collected in different books, papers and sites is presented. Concerning validity scale 10 events are selected as true and almost true, 6 tsunami events were generated by underwater earthquakes; 3 events - by volcano eruptions, and one was a teletsunami. The geographical and temporal distributions of tsunami events are studied.
\end{abstract}

Keywords: Tsunami, Caribbean Sea, guadeloupe, statistical analysis, natural hazards, ocean waves.

\section{INTRODUCTION}

Tsunami danger in the Caribbean and especially in Guadeloupe has been widely discussed in the literature. The first attempt to synchronize historical data was produced in [1], results of similar research can be found in [2], databases [3, 4]. Tsunami danger for the Lesser Antilles was studied in [5, $6]$.

Historical data was collected till 1997 in [1] who suggested that 91 reported events might have been tsunami; he also proposed a validity scale and suggested 27 of 91 reported events to be verified tsunamis; and the rest 9 - to be very likely true tsunamis.

The return period of Caribbean tsunamis is equal to 3 years. Tsunami travel time calculation for the Caribbean Sea was prepared in [7] who estimated time for a complete crossing of the Caribbean as $3.2 \mathrm{hrs}$ laterally and $1.5 \mathrm{hrs}$ meridionally. Two historical events in the Caribbean (the 1918 Puerto Rico tsunami and the 1867 Virgin Island tsunami), induced by earthquakes, were simulated in $[8,9]$. According to [10] who modeled the propagation of the Lisbon tsunami (01/11/1755), the wave amplitude east of Saba (Lesser Antilles) reached $5 \mathrm{~m}$, in fact, $7 \mathrm{~m}$ wave was observed. Numerical simulation of the 26/12/1997 debris avalanche in Montserrat (Lesser Antilles) that induced tsunami waves up to $3 \mathrm{~m}$ height was performed in [11]. The first attempt to evaluate tsunami risk in the Caribbean Sea using the numerical simulation of wave propagation from various prognostic sources was performed in [12]; as a result zones of low tsunami risk were selected.

The goal of the present paper is to revise historical tsunami data for the Guadeloupe Department that includes Guadeloupe and small neighbor islands using all available publications and results of numerical simulations. In this paper only true and almost true events are selected, and this

*Address correspondence to this author at the Physics Department, University of the French West Indies and Guiana, Pointe-à-Pitre, Guadeloupe, France; Tel: (+59) 0590 483107; Fax: (+59) 0590 483105;

E-mail: Irina.Nikolkina@gmail.com classification corresponds to the validity 4 ("Definite tsunami. Tsunami did occur. Data corroborated or deemed valid information") and 3 ("Probable tsunami. Likely or almost true tsunami occurrence. Reliable observations for corroboration are few") according to definition given in [2]. Totally, ten events are selected as true and almost true, the observed runup locations for all events are given in Fig. (1), and the corresponding runup data are presented in Table 1. Six events were generated by underwater earthquakes; three events - by the volcano eruptions, one is a teletsunami.

The geographical and temporal distributions of tsunami events are studied.

\section{TSUNAMI OF THE TECTONIC ORIGIN}

Generally, the subduction zone where the French West Indies are situated has the potential to create tsunami genetic earthquakes with magnitude up to $\mathrm{Ms}=8.3$ (1843, Guadeloupe). Totally, 6 tectonic earthquakes are selected in our analysis. The list of the events is given below in the chronicle order.

\section{April 06, 1690}

"At St. Thomas, after the earthquake the sea receded so much that one could walk about 9 to 10 fathoms [16.5-18.5 $\mathrm{m}]$ into the sea and pick out fishes on dry land. Martinique, Barbados, and St. Lucia were less strongly affected" [2]. "The earthquake caused the collapse of stone buildings at Nevis, where landslides generated on volcanic Nevis Peak caused the sea to withdraw $201 \mathrm{~m}$ from Charleston, before returning in two minutes. Guadeloupe also incurred much damage". Also at "a rocky islet called Rockadunda (Redonda Rock Island), a great part of it split and turned into the sea". Tsunami intensity (Soloviev-Imamura scale) is estimated as 1-2 $(0.5-3 \mathrm{~m})$ for the Lesser Antilles and US Virgin Islands. The event is estimated in literature as true. The source of this tsunami was an earthquake (magnitude $\mathrm{M} \sim 8$, focal depth $33 \mathrm{~km}$ ). The exact date is unknown. The coordinates of the earthquake epicenter are given in literature: $17.2^{\circ} \mathrm{N}$ 


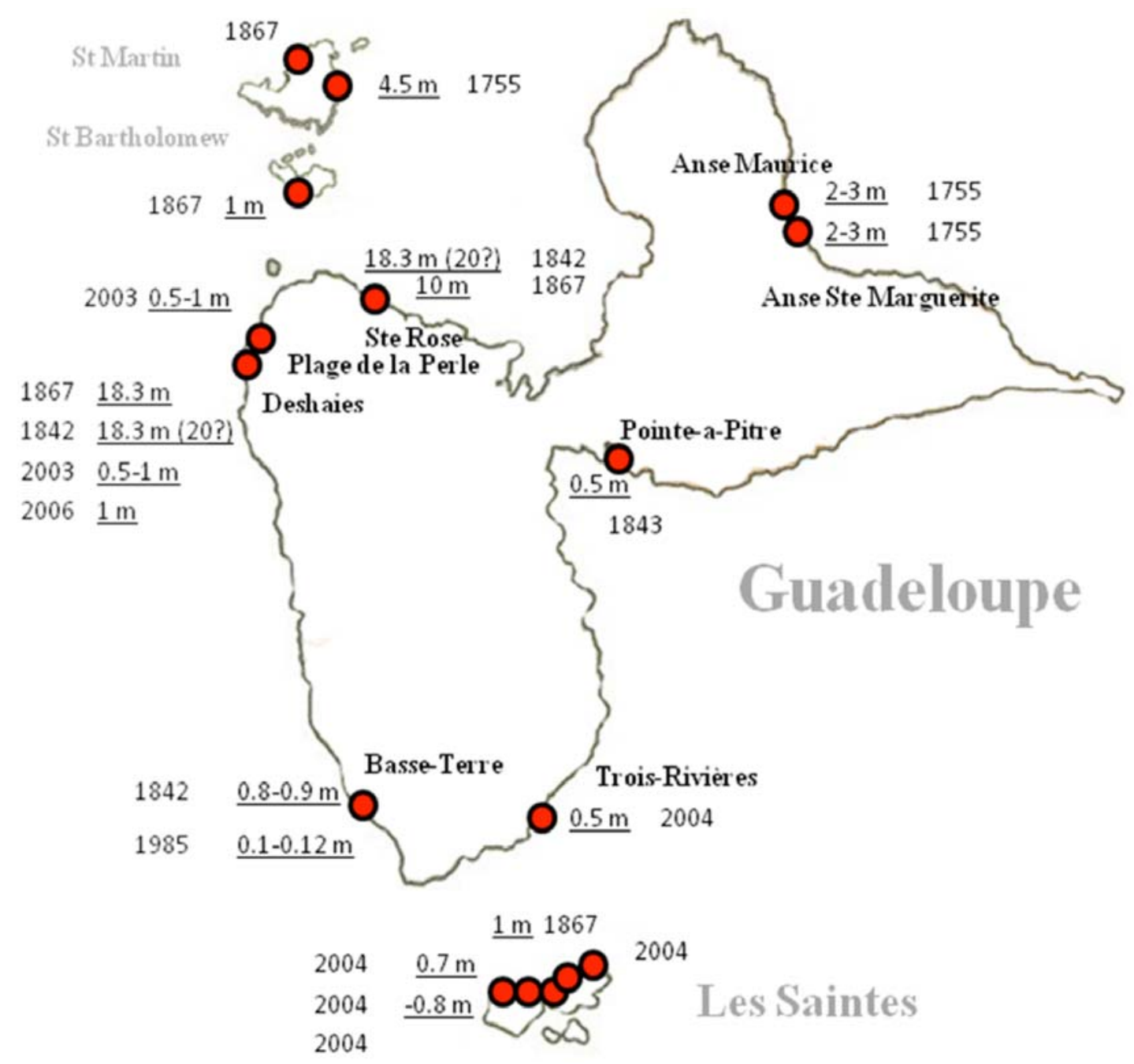

Fig. (1). Runup locations in Guadeloupe Department, St Martin and St Bartholomew.

$62.5^{\circ} \mathrm{W}$ for April 5 [3], $17.5^{\circ} \mathrm{N} 61.5^{\circ} \mathrm{W}$ for April 6 [4] and April 16 [3].

This tectonic tsunami is considered as true, although it was not recorded in Guadeloupe. Taking into account the large area of the earthquake manifestation, the tsunami in Guadeloupe can be estimated as an almost true (3) tsunami.

\section{November 30, 1827}

"Seaquake effects or a tsunami may have disturbed the ships 100 nautical leagues [564 km] west of Martinique. All the vessels near Pointe-à-Pitre (Guadeloupe) experienced the shock" [2]. Tsunami was caused by an earthquake: magnitude 6.5; epicenter coordinates $14.5^{\circ} \mathrm{N} 61^{\circ} \mathrm{W}$ [3] or $14.4^{\circ} \mathrm{N}$ $61^{\circ} \mathrm{W}$ [4]. Although the magnitude of the earthquake that caused the 1867 tsunami was rather low (6.5), it was higher than the magnitude of the 2004 earthquake in Guadeloupe (6.3) that caused a definite tsunami $50 \mathrm{~km}$ from the source. Although tsunami validity given in literature is rather low, we believe that the 1827 tsunami could be estimated as almost true (3) for Guadeloupe.

\section{February 08, 1843}

According to [2] "columns of water 100 feet high [30.5 $\mathrm{m}]$ and several feet thick [1-1.2 $\mathrm{m}]$ were observed to be ejected from fissures in the ground of Guadeloupe". The source of this tsunami was the "disastrous earthquake (magnitude 8.3; focal depth $33 \mathrm{~km}$; epicenter coordinates $16.5^{\circ} \mathrm{N}$ $62.2^{\circ} \mathrm{W}$ ) that struck Guadeloupe, leaving Pointe-a-Pitre in ruins" and damaged neighbor islands. Furthermore, in sight of the Redonda Rock Island "a mighty chunk of the rocky mass broke off and fell into the sea, which resulted in a surging rise of the ocean". Tsunami validity is estimated as a true (4) event in literature.

\section{November 18, 1867}

The huge tsunami of intensity $3(6 \mathrm{~m})$ crossed all the Lesser Antilles. According to [2] "all of Fond-du-Cure, Îles des Saintes was submerged; the water invaded the houses to a height of $1 \mathrm{~m}$. In Basse-Terre, Guadeloupe the sea swelled without any outward sign: no waves, no backwash. It rose 1 $\mathrm{m}$ in the span of 5 minutes, floating boats tied on the bank. It then dropped in the same span of time, retiring 8 to $10 \mathrm{~m}$. The same phenomenon was produced again. The difference in the extremes of the water levels was not less than $2 \mathrm{~m}$. The wave at Pointe-à-Pitre, Guadeloupe was hardly more than a swell. At Sainte-Rose, Guadeloupe the ocean suddenly withdrew more than $100 \mathrm{~m}$ from the shore. This retreat was preceded by slight oscillations from the earthquake, 
Table 1. Runup Records in Guadeloupe and Neighbor Islands

\begin{tabular}{|c|c|c|c|c|}
\hline $\mathbf{N}$ & Date & \multicolumn{2}{|c|}{ Location } & Runup, m (or citation) \\
\hline 1 & April 06, 1690 & \multicolumn{2}{|c|}{ Guadeloupe } & 4.5 \\
\hline \multirow{2}{*}{2} & \multirow{2}{*}{ November 1, 1755} & \multirow[t]{2}{*}{ Guadeloupe } & Anse Maurice & \multirow[b]{2}{*}{2.3} \\
\hline & & & Anse St Marguerite & \\
\hline 3 & November 30, 1827 & \multicolumn{2}{|c|}{ Guadeloupe } & $\begin{array}{l}\text { Seaquake effects or a tsunami disturbed the ships } 564 \mathrm{~km} \\
\text { west of Martinique. All the vessels near Pointe-à-Pitre (Gua- } \\
\text { deloupe) and in the roadsteads of Fort-de-France and Saint- } \\
\text { Pierre (Martinique) also experienced the shock. }\end{array}$ \\
\hline 4 & February 08,1843 & \multicolumn{2}{|c|}{ Guadeloupe } & $\begin{array}{l}\text { Columns of water } 100 \text { feet high }[30.5 \mathrm{~m}] \text { and several feet } \\
\text { thick }[1-1.2 \mathrm{~m}] \text { were observed to be ejected from fissures in } \\
\text { the ground of Guadeloupe. }\end{array}$ \\
\hline \multirow{3}{*}{5} & \multirow{3}{*}{ November 18,1867} & Guadeloupe & Deshaies & 18.3 \\
\hline & & \multicolumn{2}{|c|}{ St Bartholomew } & 1 \\
\hline & & \multicolumn{2}{|c|}{ Les Saintes } & 1 \\
\hline 6 & March 16,1985 & Guadeloupe & Basse-Terre & $0.10-0.12$ \\
\hline 7 & December 26, 1997 & Guadeloupe & northern coast & 2-3 (modeled) \\
\hline \multirow[t]{2}{*}{8} & \multirow[t]{2}{*}{ July 12-13, 2003} & \multirow[t]{2}{*}{ Guadeloupe } & Plage de la Perle & \multirow{2}{*}{$0.5-1$} \\
\hline & & & Deshaies & \\
\hline \multirow{2}{*}{9} & \multirow{2}{*}{ November 21, 2004} & \multirow{2}{*}{ Les Saintes } & Village of Petite Anse & water receded a distance of 2-3 m \\
\hline & & & Baie du Marigot & an unusual surge \\
\hline 10 & May 20, 2006 & Guadeloupe & Deshaies & 1 \\
\hline
\end{tabular}

which lasted perhaps 5 or 6 seconds. Then felt a first wave, of 60 feet $[19.8 \mathrm{~m}]$ in elevation, rising to the north, approximately 3 milles [5.6 km] broad, rolled violently towards the land, where it crashed, immersing the whole shore, and swamping the houses that were there. A second and third of these enormous waves rolled in from north to south, one after another, at short intervals, and like the first one, overwhelmed everything along the way. On the northwest shore at Deshaies, Guadeloupe a tsunami ravaged the town and smashed nearly all the houses. Everyone has taken refuge in the church. Houses destroyed, sea receded $100 \mathrm{~m}$ and returned as an $18.3 \mathrm{~m}$ wave". Meanwhile historical material was inspected in [5] and it was concluded that the wave height at Deshaies and Ste Rose could not exceed $10 \mathrm{~m}$, a rather $5 \mathrm{~m}$. This event was simulated in [9] in the framework of the nonlinear shallow-water theory a very good correlation between computed and historic data for all the Lesser
Antilles except Deshaies and Ste Rose (Guadeloupe) was obtained, the authors concluded that observed waves in these locations should be about 2-5 $\mathrm{m}$. The cause of the tsunami was an earthquake occurred in the Virgin Islands (magnitude 7.5; focal depth $33 \mathrm{~km}$ [4]; epicenter coordinates $18.1^{\circ} \mathrm{N}$ $65.1^{\circ} \mathrm{W}$ [4] or $18.4^{\circ} \mathrm{N} 64.3^{\circ} \mathrm{W}$ [3]. This event is a true (4) tsunami.

\section{March 16, 1985}

"A several-centimeter [0.10 - to 0.12-m] of tsunami was recorded at tide-gauge in Basse-Terre, Guadeloupe" [2]. It was generated by the earthquake (magnitude $6.3[2,3]$ or 6.4 [4]; focal depth $13 \mathrm{~km}$; epicenter location is $17.013^{\circ} \mathrm{N}$ $62.448^{\circ} \mathrm{W}$ [4], or $17^{\circ} \mathrm{N} 62.5^{\circ} \mathrm{W}$ [5], or $17.1^{\circ} \mathrm{N} 62.4^{\circ} \mathrm{W}$ [3] which was also felt in Pointe-à-Pitre, Guadeloupe and through the other Antillean islands. Furthermore, the land- 
slide at Redonda Rock Island was reported in [2]. Tsunami is a true (4) event.

\section{November 21, 2004}

A tsunami was reported for Guadeloupe in [13]: Village of Trois-Rivières (depression $0.5 \mathrm{~m}$ ), Marina de Rivière Sens, City of Basse-Terre (weak depression), for Les Saintes, Island of Terre-de-Bas: Village of Grande Anse (sea receded $5 \mathrm{~m}$ and dropped $80 \mathrm{~cm}$ ), Beach of Grande Anse (70 cm height), Village of Petite Anse (water receded a distance of 2 to $3 \mathrm{~m}$ ); and for the Island of Terre-de-Haut: Baie du Marigot ("an unusual surge" reported by a witness). The authors of this paper participated in the field survey in February 2008 that was organized to find tsunami traces on the island on Terre-de-Haut, but no traces were found. The tsunami was caused by an earthquake which occurred in Dominica Passage (between Guadeloupe and Dominica): magnitude 6.3; focal depth of $14 \mathrm{~km}$; coordinates $15.677^{\circ} \mathrm{N}$ $61.650^{\circ} \mathrm{W}$. For the French West Indies this tsunami is a true (4) event.

Totally, 6 events can be considered to be true and almost true tsunamis generated by tectonic processes; one of these events (1985) was instrumentally recorded.

It is necessary to mention a strong earthquake that occurred recently in Martinique (November 29, 2007) (19:00 UTC; magnitude $7.4 ; 14.943^{\circ} \mathrm{N}, 61.244^{\circ} \mathrm{W}$, focal depth $146.2 \mathrm{~km})$. Immediately after earthquake the authors inspected the south coast of Guadeloupe but found no tsunami traces. No report has been received from other islands of Lesser Antilles. Based on these data no tectonic tsunami event has occurred on Guadeloupe and Martinique since 2004 meanwhile a strong earthquake took place in this region.

\section{TSUNAMI OF THE VOLCANIC ORIGIN}

As known, volcanic eruptions can generate numerous destructive tsunamis in the Caribbean region: locally catastrophic, short-period tsunami-like waves can be generated directly by lateral, direct or channelized volcanic blast episodes, or in combination with collateral air pressure perturbations, nuess ardentes, pyroclastic flows, lahars, or cascading debris avalanches. Submarine volcanic caldera collapses can also generate local destructive tsunami waves [14]. Totally, 3 events are selected to be true and almost true, the list of volcanic events is given in the chronicle order.

\section{December 26, 1997}

3-meter runup was observed in Montserrat, at Old Road Bay where the wave rolled northwards parallel to the coast, ending up at Old Road Bay, $10 \mathrm{~km}$ from the White River Valley. Debris avalanche from the volcano entered in the sea through the River Valley. Formally, the tsunami was not recorded in Guadeloupe. Meanwhile according to the numerical modeling [11], tsunami waves of 2-3 m could reach Guadeloupe and Antigua (50 km from Montserrat) in 10 minutes. Based on similar events of 12/07/2003 and 20/05/2006 (see below) and numerical simulations of Heinrich et al. [11] we estimate the 1997 tsunami as an almost true (3) tsunami for Guadeloupe.

\section{July 12, 2003}

The cause of tsunami was the collapse of a lava dome that occurred at the Soufrière Hills Volcano in Montserrat, the Lesser Antilles. A tsunami was generated when a very large pyroclastic flow impacted the sea. The authors provided a field survey to investigate this event. According to [15] in Deshaies Guadeloupe water rose $1.5 \mathrm{~m}$ near the entry to the port and surged $25 \mathrm{~m}$ inland; on the beach Plage de la Perle the sand level had increased by up to $50 \mathrm{~cm}$. According to [15] who modeled this event, the maximum wave amplitudes were equal to $1.6 \mathrm{~m}$ in Guadeloupe. We consider this tsunami as a true (4) event.

\section{May 20, 2006}

A major lava dome collapse took place at the Soufriere Hills Volcano (Montserrat). According to [16], the effects of the tsunami were felt in the harbor of Deshaies, Guadeloupe. The eye-witness said that "the level of the river roused quickly to a height of approximately $60-70 \mathrm{~cm}$. Two small fishing boats moored in the mouth were slightly damaged." This event is estimated as true (4) for Guadeloupe.

Recently historic and potential flank-collapse of the Soufriere Volcano on Guadeloupe which can be a source of volcanic tsunamis in Guadeloupe has been studied in [17]. Meanwhile, just now there are no historic data of tsunamis from the Guadeloupe volcano; the years of historical eruptions of Soufriere $(1797,1798$, and 1836) are not associated in the literature with any unusual sea agitation in the Caribbean.

\section{TELE TSUNAMI}

\section{November 1, 1755}

The event was generated by a well-known Lisbon earthquake (magnitude 8.5-9; focal depth 20-40 km; epicenter coordinates $37^{\circ} \mathrm{N} 11^{\circ} \mathrm{W}$ ) that produced huge tsunami with maximal height of 10 meters, which propagated across the Atlantic Ocean and affected the American Coast, in particular, the Lesser Antilles. "In Martinique and most of the French Islands, it overflowed the low land, and returned quickly to its former boundaries" [2]. Recently, the probable geological evidence of the 1755 tsunami on the east coast of Grande-Terre (Guadeloupe) at Anse Sainte Marguerite and Anse Maurice on a height of 2-3 $\mathrm{m}$ has been found in [18].

\section{ANALYSIS OF TSUNAMI OCCURRENCE IN GUADELOUPE}

The data of tsunami in Guadeloupe Department and neighbor islands for 1498-2008 (510 years) collected above is analysed. The total number of tsunamis is ten (six of tectonic origin, three of volcanic origin and one teletsunami). The only teletsunami occurred in 1755 in the region (wellknown Lisbon event). Volcanic tsunamis were caused by Soufriere Hills (Montserrat) eruptions during the last decade. The variability of the number of tsunamis in 50-yr and $100-y r$ intervals is studied. The maximum number of events (all of the tectonic origin) occurred in $1800-1849$ period. The increase of the volcanic events is vivid; all of them were caused by the activity of volcano in Montserrat in last decade. 


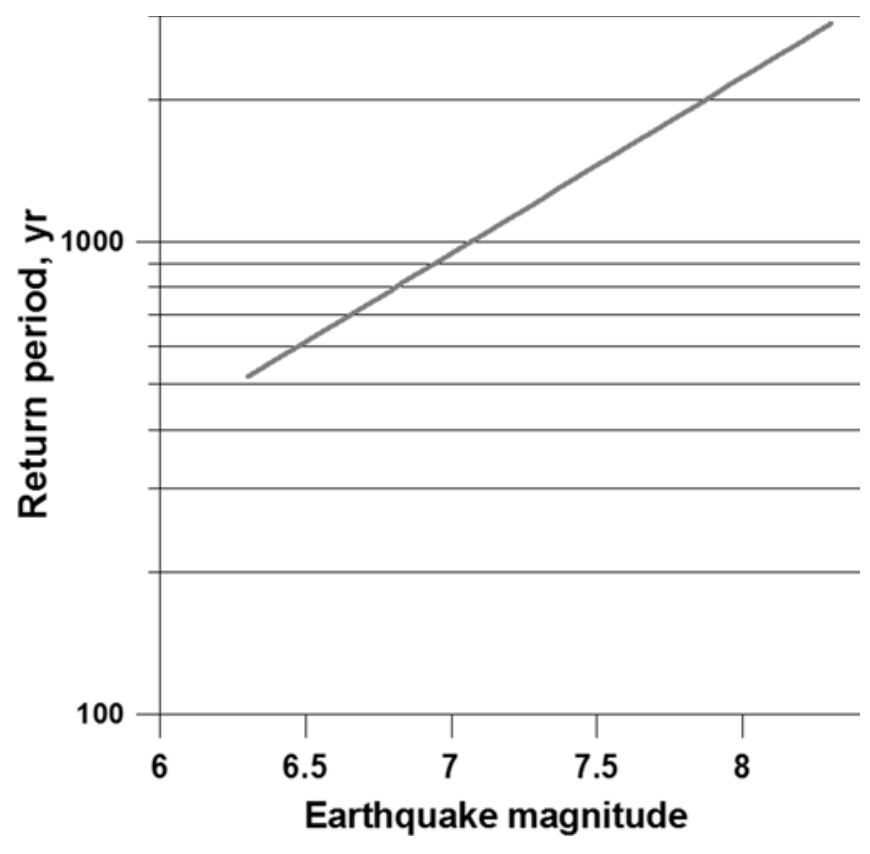

Fig. (2). Return period of tectonic tsunamis in Guadeloupe versus earthquake magnitude.

For all local tectonic events magnitude values are given. The cumulative frequency of tsunamis generated by earthquakes with given parameters is calculated.

These data are fitted very well by the exponential curve with $\mathrm{R}=0.97$ (time is in years):

$$
\ln (N / T)=-0.86 M+0.83,
$$

As a result, the return period versus magnitude can be determined, see Fig. (2),

$$
T=2.6 \cdot \exp (0.86 M)
$$

In fact, earthquakes with a magnitude more than 6.3 can generate tsunami; but return period of such tsunamis is more than 200 yrs. As for event with magnitude 8, all strong earthquakes occurred before 1843 and the accuracy of this estimation is very low. Meanwhile, runup values varies from $0.1 \mathrm{~m}$ to $1 \mathrm{~m}$ irrespective of magnitude, if the values of 10 , 18 and $20 \mathrm{~m}$ (doubtfulness of these data was discussed previously) are not taken into account.

\section{CONCLUSION}

According to historical data tsunami in Guadeloupe is a relatively frequent event; ten tsunamis are selected as true and almost true. Six events were generated by underwater earthquakes; three - by volcano eruptions; and one is a teletsunami. Tsunamis of volcanic origin were induced by Montserrat volcano in last decade. Tsunamis of seismic origin are generated by earthquakes with magnitude more than 6.3. Runup values varies from $0.1 \mathrm{~m}$ to $1 \mathrm{~m}$ irrespective of magnitude for tectonic events (expect abnormal values of the height in 10 or $18 \mathrm{~m}$ for Deshaies, Guadeloupe). The possibility of big tsunami which heights exceeds $5 \mathrm{~m}$ for Guadeloupe is questionable. Recently Scheffers and Kelletat [19] reported geological traces of tsunami $3 \mathrm{~m}$ height that oc- curred in St. Martin (exactly, on small unnamed island of volcanic rocks at eastern St. Martin) in Holocene (500 BP); this confirm low probability of big tsunami for Guadeloupe. It is necessary to mention that since the coastal utilization is much denser comparing to historical time, it must be taken into account in mitigation strategies that the smaller tsunamis with higher probabilities would also be effective and cause loss of property and life in Guadeloupe.

\section{ACKNOWLEDGEMENTS}

Partial support came from University of the French WestIndies Guiana and RFBR (08-05-00069, 09-05-00204) is gratefully acknowledged. We thank Professor Ahmet Cevdet Yalçiner for his comments that have helped to improve this paper.

\section{REFERENCES}

[1] Lander, JF, Whiteside, LS, Lockridge, PA. A brief history of tsunami in the Caribbean Sea. Sci Tsunami Hazards 2002; 20: 5794.

[2] O'Loughlin, KF, and Lander, JF. Caribbean Tsunamis: A 500-Year History from 1498-1998, Adv Nat Technol Hazards Rese 2003; p. 20.

[3] HTDB/ATL Expert Tsunami Database for the Atlantics. Version 3.6 of March 15, 2002. Tsunami Laboratory, Novosibirsk, Russia, 2003.

[4] NGDC (National Geophysical Data Center) Tsunami Database, http://www.ngdc.noaa.gov/seg/hazard/tsu_db.shtml, 2006

[5] Zahibo N, Pelinovsky E. Evaluation of tsunami risk in the Lesser Antilles. Nat Hazards Earth Sci 2001; 3: 221-31.

[6] Zahibo N, Pelinovsky, E. In: Mercado-Irizarry A, Liu P, Eds. Caribbean Tsunami Hazard: Tsunamis in the Lesser Antilles, Caribbean Tsunami Hazard. World Sci Singapore 2006; 244-54.

[7] Weissert TP. Tsunami travel time charts for the Caribbean. Sci Tsunami Hazards 1990; 8: 67-78.

[8] Mercado, A, McCann, W. Numerical simulation of the 1918 Puerto Rico tsunami. Nat Hazards 1998; 18: 57-76.

[9] Zahibo N, Pelinovsky E, Yalciner et al. The 1867 Virgin Island Tsunami: observations and modeling. Oceanol Acta 2003a; 26 : 609-21.

[10] Mader, CL. Modeling the 1755 Lisbon tsunami. Sci Tsunami Hazards 2001; 9: 93-98.

[11] Heinrich, F, Guibourg, S, Mangeney, A, Roche, R. Numerical modelling of a landslide-generated tsunami following a potential explosion of the Montserrat Volcano. Phys Chem Earth 1999; A24: 163-168.

[12] Zahibo N, Pelinovsky E, Kukin A, Kozelkov A. Estimation of farfield tsunami potential for the Caribbean Coast based on numerical simulation. Sci Tsunami Hazards 2003b; 21(4): 202-22.

[13] Zahibo N, Pelinovsky E, Okal E, et al. The earthquake and tsunami of November 21, 2004 at Les Saintes, Guadeloupe, Lesser Antilles. Sci Tsunami Hazards 2005; 23(1): 25-39.

[14] Pararas-Carayannis, G. In: Mercado-Irizarry A, Liu P, Eds. Caribbean Tsunami Hazard: Risk assessment of tsunami generation from active volcanic sources in the Eastern Caribbean Region. World Sci, Singapore 2006; 91-137.

[15] Pelinovsky E, Zahibo N, Dunkley P, et al. Tsunami generated by the volcano eruption on July 12-13 2003 at Montserrat, Lesser Antilles. Sci Tsunami Hazards 2004; 22(1): 44-57.

[16] Zahibo N. Deshaies, Guadeloupe tsunami, 20 May 2006, Montserrat, Lesser Antilles, Soufriere volcano tsunami. Tsunami Newsletter 2006; XXXVIII, 2: 4-5.

[17] Le Friant A, Boudon G, Komorowski J-C, Heinrich P, Semet MP Potential flank-collapse of Soufriere Volcano, Guadeloupe, Lesser Antilles? Numerical simulation and hazards. Nat Hazards 2006; 39: 381-393.

[18] Morton RA, Richmond BM, Jaffe BE, Gelfenbaum G. Reconnaissance investigation of Caribbean extreme wave deposits - prelimi- 
nary observations, interpretations, and research directions, USGS, Open-File Report 2006-1293, 2006; p. 46.

[19] Scheffers A, Kelletat D. In: Mercado-Irizarry A, Liu P, Eds. Caribbean Tsunami Hazard: new evidence and dating of Holocene paleo- tsunam events in the Caribbean (Barbados, St. Martin and Angulilla). World Sci Singapore 2006; 178-202.

Received: October 20, 2009

Revised: November 29, 2009

Accepted: December 02, 2009

(C) Nikolkina et al.; Licensee Bentham Open.

This is an open access article licensed under the terms of the Creative Commons Attribution Non-Commercial License (http://creativecommons.org/licenses/_by-nc/3.0/) which permits unrestricted, non-commercial use, distribution and reproduction in any medium, provided the work is properly cited. 